удк 005.339

\title{
АНАЛІЗ ТЕОРЕТИЧНИХ ПІДХОДІВ ДО ВИЗНАЧЕННЯ СУТНОСТІ ЗОВНІШНЬОГО СЕРЕДОВИЩА МІЖНАРОДНОГО БІЗНЕСУ ПІДПРИЕМСТВА
}

\section{ANALYSIS OF THEORETICAL APPROACHES TO DETERMINATION OF THE ESSENCE OF THE EXTERNAL ENVIRONMENT OF THE INTERNATIONAL BUSINESS OF THE ENTERPRISE}

\author{
Шталь Тетяна Валеріївна \\ доктор економічних наук, професор, \\ Харківський національний економічний університет імені Семена Кузнеця \\ ORCID: https://orcid.org/0000-0003-1256-9854 \\ Бунчикова Тетяна Сергіївна \\ магістр, \\ Харківський національний економічний університет імені Семена Кузнеця \\ ORCID: https://orcid.org/0000-0001-6040-1293
}

Shtal Tatyana, Bunchykova Tatyana

Simon Kuznets Kharkiv National University of Economics

\begin{abstract}
Стаття присвячена обґрунтуванню доцільності та нагальної необхідності дослідження зовнішнього середовища суб'єктів господарювання в умовах сучасних докорінних змін у світовій економічній системі. Досліджуючи підприємство як відкриту систему, яка функціонує в умовах турбулентності світових ринків, доцільно виокремлювати його зовнішнє та внутрішнє середовище. При цьому не можна спрощено розглядати їх як за змістом, так і за с структурою. В економічній літературі існує значна кількість наукових визначень щодо сутності поняття «зовнішнє середовище», однак єдиного підходу до тлумачення даної дефрініції, на думку авторів, не існує. Даний фракт і обумовлює доцільність поглибленого дослідження наукових напрацювань у даному аспекті. В статті авторами проведений критеріальний аналіз існуючих визначень сутності зовнішнього середовища фрункціонування підприємства, виокремлено та запропоновано підходи до структурування наукових поглядів та надано власне його трактування для поглибленого виявлення його характерних особливостей у сорері міжнародного бізнесу.
\end{abstract}

Ключові слова: міжнародний бізнес, зовнішнє середовище, аналіз, критерії, узагальнення, підприємство.

Статья посвящена обоснованию целесообразности и острой необходимости исследования внешней среды субъектов хозяйствования в условиях современных коренных изменений в мировой экономической системе. Исследуя предприятие как открытую систему, которая ффункционирует в условиях турбулентности мировых рынков, целесообразно выделять его внешнюю и внутреннюю среду. При этом нельзя упрощенно рассматривать их как по содержанию, так и по с структурой. В экономической литературе существует значительное количество научных определений относительно сущности понятия «внешняя среда», однако единого подхода к толкованию данной десиниции, по мнению авторов, не существует. Данный фракт и обусловливает целесообразность углубленного исследования научных наработок в данном аспекте. В статье авторами проведен критериальный анализ существующих определений сущности внешней среды функционирования предприятия, выделены и предложены подходы к структурированию научных взглядов и предоставлено собственно его трактовки для углубленного выявления его характерных особенностей в сорере международного бизнеса.

Ключевые слова: международный бизнес, внешняя среда, анализ, критерии, обобщения, предприятие.

The article is devoted to the substantiation of expediency and urgent need to study the external environment of economic entities in the conditions of modern radical changes in the world economic system. The current development of international economic activity of domestic economic entities is characterized by increasing influence of the external environment of their operation, and it is in the context of the global COVID-19 pandemic that this influence 
has changed both in nature and strength. Today, the international environment is quite diversified and hierarchical, so there is no doubt about the need to study it to develop sound management decisions when companies enter new foreign markets or expand their activities in existing markets. Over the past two years, the world community has failed to provide more or less effective ways or methods of adapting businesses to the ever-changing and, in many cases, completely unpredictable, conditions of doing business. And it is not only about the significant volatility of world markets due to the changing world conditions, but also about the change in the conditions of cooperation with the country's counterparties due to significant protectionist measures at the macro level. In these conditions, the question of studying the theoretical aspects of the content and structure of the external environment of enterprises in the international sphere is urgent. Exploring the enterprise as an open system that operates in conditions of turbulence in world markets, it is advisable to distinguish between its external and internal environment. At the same time it is impossible to consider them simplified both on the maintenance, and on with structure. In the economic literature there is a significant number of scientific definitions of the essence of the concept of "environment", but a single approach to the interpretation of this definition, according to the authors, does not exist. This fact determines the feasibility of in-depth study of scientific developments in this aspect. In the article the authors carried out a criterion analysis of the existing definitions of the essence of the external environment of the enterprise, singled out and proposed approaches to structuring scientific views and provided its own interpretation for in-depth identification of its characteristics in international business.

Keywords: international business, external environment, analysis, criteria, generalization, enterprise.

Постановка проблеми. Сучасний розвиток міжнародної економічної діяльності вітчизняних суб'єктів господарювання характеризується посиленням впливу зовнішнього середовища їх фуннкціонування і саме в умовах світової пандемії COVID-19 цей вплив змінився як за характером, так і за силою. Міжнародне середовище на сьогодні $€$ достатньо розгалуженим і ієрархічним, тому не викликає сумнівів необхідність його дослідження для вироблення обґрунтованих управлінських рішень при виході підприємств на нові закордонні ринки або ж розширенні своєї діяльності вже на існуючих ринках. За останні два роки світова спільнота не змогла надати більш-менш дієві способи або ж методи адаптації суб'єктів господарювання до постійно мінливих і, а багатьох випадках зовсім непрогнозованих, умов ведення бізнесу. I мова йде не тільки про значну волатильність світових ринків через мінливість світової кон'юнктури, а й про зміну умов співробітництва 3 контрагентами країн через значні протекціоністські заходи на макрорівні. В цих умовах нагальним $€$ питання дослідження теоретичних аспектів змісту та структури зовнішнього середовища підприємств у міжнародній ссрері.

Аналіз останніх досліджень та публікацій. Дослідженням проблематики впливу зовнішнього середовища на міжнародну економічну діяльність підприємства присвячено багато наукових праць сучасних учених, а саме: І. Ансофрфа, М. Портера, Т. В. Шталь, Я. О. Полякової, В. О. Василенко, Т. І. Ткаченко, Т. О. Примак, В.М. Нижника, І. М. Тесленок, 3. $€$. Шершньової та ін.

Виділення невирішених раніше частин загальної проблеми. В економічній літера- турі існує значна кількість наукових визначень щодо сутності поняття «зовнішнє середовище», однак єдиного підходу до тлумачення даної десрініції, на думку автора, не існує. Даний фракт і обумовлює доцільність поглибленого дослідження наукових напрацювань у даному аспекті.

Формулювання цілей статті (постановка завдання). Метою статті $\epsilon$ теоретичне обґрунтування значущості зовнішнього середовища у міжнародній економічній діяльності підприємства та систематизація наукових підходів щодо його визначення.

Виклад основного матеріалу. Досліджуючи підприємство як відкриту систему, яка срункціонує в умовах турбулентності світових ринків, доцільно виокремлювати його зовнішнє та внутрішнє середовище. При цьому не можна спрощено розглядати їх як за змістом, так і за с структурою.

У підручнику з менеджменту М. Мескона, М. Альберта і Ф. Хедоурі поняття зовнішнього середовища як окремої десрініції не існує. Натомість вчені ототожнюють це поняття 3 поняттями «нестабільне зовнішнє середовище $[13$, с. 688$]$, «оточення прямого впливу» $[13$, с. 689], «рухливість зовнішнього оточення - відносна швидкість зміни зовнішнього середовища організації» [13, с. 691].

В економічному словнику під редакцією О. М. Азріліяна під зовнішнім середовищем організації розуміється «все, що впливає на організацію з навколишнього середовища» [1, с. 994].

В економічному словнику під редакцією Л. І. Лопатнікова зовнішнє середовище - це «те, що оточує систему і впливає на неї» [12].

У роботі С. Г. Натрошвілі зовнішнє середовище представлено як «сукупність інституцій 
та процесів, що фрункціонують поза межами організації» [14, с. 47].

У науковій праці Т. О. Примак зовнішнє середовище є сукупністю «суб'єктів господарювання, економічних, суспільних і природних умов, що діють у глобальному оточенні» [20].

Схожої думки дотримується і М. О. Полутова, визначаючи зовнішнє середовище як «сукупність активнихгосподарюючихсуб'єктів, економічних, суспільних і природних умов, національних та міждержавних, інституційних структур й інших зовнішніх умов і фракторів, що діють в оточенні підприємства та впливають на різні сорери його діяльності» [19, с. 82].

На думку О. О. Репіної, Т. Ю. Анопченко та Р. С. Володіна, зовнішнє середовище - це «сукупність фракторів (умов та організацій), які мають вплив на діяльність фрірми» [21].

Вчені А. М. Кармінський, Н. І. Оленев, А. Г. Примак, С. Г. Фалько у роботі [8, с. 113] трактують зовнішнє середовище як сукупність «економічних і політичних суб'єктів, що діють за межами підприємства, і відносини, що складаються між ними і підприємством. Відносини визначають взаємодію між підприємством, його реальними і потенціальними клієнтами, а також конкурентами». Ці відносин автори представляють у вигляді «зовнішніх інорормаційних потоків підприємства», таких, як міжнародні, економічні, політичні, конкурентні, технологічні, ринкові та соціальні [8, с. 114].

Схожа позиція викладена i у праці Д. О. Горєлова, який акцентує увагу а тому, що зовнішнє середовище $є$ сукупністю «господарських суб'єктів, економічних, суспільних і природних умов, національних та міждержавних інституційних структур та інших зовнішніх щодо підприємства умов і чинників» [3, с. 22]. I саме в цьому визначенні враховується не просто макрорівневий аспект зовнішнього середовища, а міждержавний (метарівневий).

У науковій праці І. О. Щебликіної та Д. В. Грибової зовнішнє середовище організації (організаційне оточення) розглядається як сукупність фракторів, що перебувають за її межами, з якими вона взаємодіє [26].

Схожої позиції дотримуються науковці О. В. Капліна та Д. О. Зайченко, які у своїй роботі розглядають зовнішнє середовище як сукупність зовнішніх фракторів, з якими суб'єкти економічної діяльності взаємодіють та які повинні враховуватися в їх діяльності [7, с. 26].

Аналогічний підхід викладено і у роботі 3. Є. Шершньової, згідно з яким зовнішнє середовище - це «сукупність фракторів, що фрормують довгострокову прибутковість (збитковість) організації і на які організація не може впливати взагалі або має незначний вплив» [24, с. 67].

Так, О. О. Гуторова зазначає, що «середовище організації - це сили, зовнішні стосовно до організації, які впливають на їі результативність» [4, с. 77].

В. О. Василенко та Т. І. Ткаченко під зовнішнім середовищем розуміють всі умови і фрактори, що виникають у навколишньому середовищі, незалежно від діяльності конкретної фірми, але що роблять чи здатні вплинути на її функціонування і тому потребують врахування у прийнятті управлінських рішень. Вчені наголошують, що зовнішнє середовище - це не тільки середовище реалізації її продукту, але це ще і сорера, що постійно надає нові можливості для розвитку бізнесу організації; - це своєрідний чи особливий бізнес-ресурс організації [2].

У роботі О. І. Петкова під зовнішнім середовищем розуміються «фрактори та умови, що перебувають поза підприємством та існують незалежно від нього, але мають вплив на його діяльність» [17, с. 36].

А в роботі С. Г. Дзюби і І. Ю. Гайдай зовнішнім середовищем вважається сукупність «суб'єктів і чинників, які діють за його межами» [6, с. 147].

В науковій праці А. К. Нестерова дається вже більш розширене трактування зовнішнього середовища організації як «сукупності факторів і ресурсів, які забезпечують організацію необхідним для реалізації внутрішнього потенціалу на потрібному для підтримки еорективності організації рівні» [15]. Тобто автор включає і ресурсну складову до даного визначення, доповнюючи його і за змістом, і за масштабом охоплення.

Найбільш широке трактування надається у роботі Ю. В. Дегтярьова, де зовнішнє середовище $\epsilon$ «сукупністю економічних, політичних, правових, наукових і технічних, комунікаційних, природно-геограсрічних та інших умов і фракторів, які виходять за межі організації і здійснюють прямий або непрямий вплив на діяльність підприємницького підприємства» [5, с. 115].

Як прихильника системного підходу можна розглядати точку зору Н. В. Карпової, яка стверджує, що зовнішнє середовище «являє собою систему соціальних, політичних, економічних фракторів, явищ, процесів, які безпосередньо впливають на внутрішній зміст і формування стратегії управлінських впливів» [9, с. 2083].

Достатньо спрощене визначення зовнішнього середовища надається у роботі Г. Г. Савіної та Т. І. Скібіної - «під зовнішнім середови- 
щем підприємства слід розуміти сукупність елементів, що оточують його та спричиняють на діяльність суттєвий вплив» [22].

У роботі Л. Г. Шморгун зовнішнє середовище організації $\epsilon$ сукупністю «елементів, які не входять до складу організації, але справляють на неї певний вплив» [25], але не зрозуміло які елементи і як впливатимуть на діяльність організації, що знижує теоретичну цінність такого визначення.

Подібні за змістовністю визначення надані у роботі Ю. М. Лапигін, який під зовнішнім середовищем розглядає «сукупність об'єктів, які не є елементами даної системи і взаємодія з якими враховується при вивченні системи» $[11$, с. 73]. На нашу думку, не можна ототожнювати поняття «об'єкт» та «елемент», так як вони знаходяться у різній змістовній площині.

Ще більш заплутаним та викликаючим дискусію $€$ визначення Н. І. Петренко та Т. А. Бутинець, які розглядають зовнішнє середовище як «сукупність об'єктів/суб'єктів, що не входять до системи, зміна властивостей i/або поведінка яких впливає на систему, що вивчається, а також тих об'єктів/суб'єктів, властивості яких i/або поведінка яких змінюються в результаті поведінки системи» [18, с. 372]. У самому визначенні при використанні можливої варіації i/або виникає неоднозначність розуміння, яка тільки вносить плутанину у категоріальний апарат та в подальшому може привести до хибних висновків щодо характеру його впливу та можливих наслідків.

У наукових роботах з досліджуваної тематики $є$ окремий напрям, в рамках якого вчені досліджують зовнішнє середовище не просто як систему, а як систему систем, як сукупність систем, обґрунтовуючи таким чином складність даного економічного поняття та комплексність при його аналізі та оцінці.

Так, у роботі В. М. Чернишова та А. В. Чернишова зовнішнє середовище $€$ набором «існуючих в просторі та в часі об'єктів (систем), які, як передбачається, діють на систему. Зовнішнє середовище являє собою сукупність природних і штучних систем, для яких дана система не $є$ фрункціональною підсистемою» [23, с. 8].

Аналогічно розглядає зовнішнє середовище і Д. В. Кіпа: як сукупність зовнішніх по відношенню до границь підприємства систем і параметрів, які мають на нього вплив і не можуть бути керованими підприємством $[10$, c. 323].

У науковій роботі К. Є. Орлової зовнішнє середовище виступає як складна система, яка «фрункціонує у відповідності до визначених закономірностей, має певні особливості та характеристики». До характеристик зовнішнього середовища автор відносить взаємозв'язок і взаємообумовленість його сракторів, складність, динамічність та невизначеність [16, с. 80].

Для узагальнення результатів проведеного дослідження в табл. 1 наведений аналіз існуючих теоретичних підходів до визначення сутності зовнішнього середовища підприємства.

В якості критеріїв було запропоновано розглянути змістовну наповнюваність кожного визначення за основними ключовими словами.

Досліджуючи наукові економічні праці можна дійти висновку про більш складний характер сучасний трактувань зовнішнього середовища та значну різноспрямованість акценту на включенні певних змістовних елементів до його визначення.

Слід зазначити, що всі вчені при визначенні сутності зовнішнього середовища використовують системність як основний критерій при формулюванні власного трактування.

Використовуючи субстанціональність розглянутих тлумачень, пропонується виокремити такі наукові підходи у визначенні поняття «зовнішнє середовище»:

1) процесний, представники якого розглядають зовнішнє середовище як п сукупність певних процесів;

2) фракторний підхід, представники якого акцентують увагу на зовнішньому середовищі як певній сукупності фракторів;

3) фракторно-умовний, представники якого включають до змісту зовнішнього середовища нарівні $з$ фракторами ще й певні умови;

4) структурний підхід, представники якого розглядають зовнішнє середовище як сукупність суб'єктів та елементів, які і фрормують його структуру;

5) системно-структурний підхід, прихильники якого розглядають зовнішнє середовище не просто як систему, а сукупність систем, що формують складну ієрархію взаємозв'язків між його елементами.

Підводячи підсумки власного дослідження, пропонуємо під зовнішнім середовищем підприємства розуміти сукупність суб'єктів, фракторів, умов, які впливають та результативність діяльності підприємства та обумовлюють розробку заходів з адаптації до зміни їх стану та характеру прояву.

Сучасна міжнародна діяльність суб'єктів господарювання здійснюється в умовах високого рівня невизначеності та не прогнозова- 
Критеріальний аналіз існуючих теоретичних підходів до визначення сутності зовнішнього середовища підприємства

Таблиця 1

\begin{tabular}{|c|c|c|c|c|c|c|c|c|}
\hline \multirow[b]{2}{*}{ Автори } & \multicolumn{8}{|c|}{ Зовнішнє середовище - це сукупність } \\
\hline & $\begin{array}{l}\stackrel{m}{E} \\
\frac{5}{\omega} \\
00 \\
0\end{array}$ & 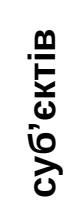 & 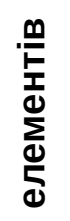 & $\begin{array}{l}\frac{m}{0} \\
\frac{d}{\partial} \\
\frac{0}{E}\end{array}$ & $\begin{array}{l}\frac{n}{0} \\
\frac{0}{0} \\
\frac{5}{0} \\
\frac{\pi}{0}\end{array}$ & $\sum_{\substack{\infty \\
\hdashline}}^{\infty}$ & త్ & $\begin{array}{l}\frac{5}{0} \\
\frac{5}{0} \\
\frac{5}{0}\end{array}$ \\
\hline С. Г. Натрошвілі [1] & & & & + & & & & \\
\hline О. О. Гуторова [4] & & & & & & & + & \\
\hline $\begin{array}{l}\text { А. М. Кармінський, } \\
\text { Н. І. Оленев, } \\
\text { А. Г. Примак, } \\
\text { С. Г. Фалько [8] }\end{array}$ & & + & + & & & & & \\
\hline Д. О. Горєлов [3] & & + & & & + & + & & \\
\hline М. О. Полутов [19] & & + & & & + & + & & \\
\hline $\begin{array}{l}\text { О. О. Репіна, } \\
\text { Т. Ю. Анопченко, } \\
\text { Р. С. Володін [21] }\end{array}$ & & 4 & & & + & + & & \\
\hline Т. О. Примак [20] & & + & & & & + & & \\
\hline $\begin{array}{l}\text { І. О. Щебликіна, } \\
\text { Д. В. Грибова [26] }\end{array}$ & & & & & + & & & \\
\hline $\begin{array}{l}\text { О. В. Капліна } \\
\text { та Д. О. Зайченко [7] }\end{array}$ & & & & & + & & & \\
\hline 3. Є. Шершньова [24] & & & & & + & & & \\
\hline $\begin{array}{l}\text { В. О. Василенко, } \\
\text { Т. І. Ткаченко[2] }\end{array}$ & & & & & + & + & & \\
\hline О. І. Петков [17] & & & & & + & + & & \\
\hline $\begin{array}{l}\text { С. Г. Дзюба, } \\
\text { І. Ю. Гайдай [6] }\end{array}$ & & + & & & + & & & \\
\hline А. К. Нестеров [15] & & & & & + & & & \\
\hline Н. В. Карпова [] & & & & + & + & & & \\
\hline $\begin{array}{l}\text { Г. Г. Савіна, } \\
\text { Т. І. Скібіна [22] }\end{array}$ & & & + & & & & & \\
\hline Л. Г. Шморгун [25] & & & + & & & & & \\
\hline Ю. В. Дегтярьов [5] & & & & & + & + & & \\
\hline Ю. М. Лапигін [11] & + & & & & & & & \\
\hline $\begin{array}{l}\text { Н. І. Петренко, } \\
\text { Т. А. Бутинець [18] }\end{array}$ & + & + & & & & & & \\
\hline $\begin{array}{l}\text { В. М. Чернишов, } \\
\text { А. В. Чернишов [23] }\end{array}$ & & & & & & & & + \\
\hline К. Є. Орлова [16] & & & & & + & & & + \\
\hline Д. В. Кіпа [10] & & & & & & & & + \\
\hline
\end{tabular}

ності. Фактори, якими можна було нехтувати ще п'ять-сім років, на сьогодні мають першочергове значення, що має відбиватись в умовах міжнародних контрактів, пошуку нових партнерів, аналізі та оцінці релевантного середовища.

Складність управління міжнародною економічною діяльністю підприємства, у вирішальній мірі визначається складністю та невизна- ченістю зовнішнього середовища, постійні зміни якого впливають на ефрективність фрункціонування підприємства як суб'єкту ЗЕД. Тому дослідження зовнішнього середовища $\epsilon$ необхідним у процесі управління міжнародною економічною діяльністю підприємства, що обумовлюється такими причинами: вплив зовнішнього середовища на стан міжнародної економічної діяльності вітчизняних підпри- 
ємств є визначальним в умовах транзитивної економіки; аналіз зовнішнього ринку, визначення глибинних чинників конкуренції на ньому, напряму та інтенсивності тиску з боку кожного із них висвітлює найважливіші сильні та слабкі місця міжнародної економічної діяльності підприємства, стимулює підприємство до позиціонування, тобто пошуку такого положення на зовнішньому ринку, за яким воно здатне найкраще захиститися від впливу негативних чинників та застосувати на свою користь вплив позитивних факторів; аналіз зовнішнього ринку є фундаментом для розробки та формулювання ефективної стратегії розвитку міжнародного бізнесу підприємства, яка ґрунтується на концепції менеджменту підприємства як відкритої системи, внутрішній стан якої залежить від умов зовнішнього середовища. I навіть якщо в самому внутрішньому стані підприємства не відбувається ніяких змін, постійні зміни зовнішнього середовища чинять суттєвий вплив на результативність його міжнародної діяльності, рівень його адаптаційних можливостей до змінних вимог зовнішнього середовища.

Отже, можна стверджувати про взаємозв'язок та взаємний вплив зовнішнього середовища і міжнародної економічної діяльності підприємства: саме від ступеню прогнозованості, характеру та рівня впливу факторів зовнішнього середовища залежить, насамперед, місія компанії і подальша стратегія їі зовнішньоекономічного розвитку, але і від специфріки економічної поведінки компанії багато в чому залежить структура та домінування певних фракторів зовнішнього середовища.

\section{СПИСОК ВИКОРИСТАНИХ ДЖЕРЕЛ:}

1. Большой экономический словарь / под ред. А. Н. Азрилияна. Москва : Институт новой экономики, 1999. 1248 с.

2. Василенко В. А., Ткаченко Т. І. Стратегічне управління : навч. посіб. Київ : ЦУЛ, 2003. 396 с.

3. Горєлов Д. О. Стратегія підприємства : навч.-метод. посіб. Харків : Вид-во ХНАДУ, 2010. 133 с.

4. Гуторова О. О. Основи менеджменту: навчальний посібник. Харків : ХНАУ, 2009. 327 с.

5. Дегтярева Ю. В. Компоненты внешнего и внутреннего окружения инвестиционного проекта. Науковий вісник Ужгородського національного університету. Серія : Міжнародні економічні відносини та світове господарство. 2016. Вип. 7. Ч. 1. С. 114-117.

6. Дзюба С. Г., Гайдай І. Ю. Загальна характеристика зовнішнього середовища фрункціонування підприємств. Актуальні проблеми економіки. 2012. № 1. С. 144-156.

7. Каплина О. В., Зайченко Д. А. Оценка конкурентоспособности предприятия на основе процессного похода. Маркетинг. 2005. № 4. С. 24-38.

8. Карминский А. М., Оленев Н. И., Примак А. Г., Фалько С. Г. Контроллинг в бизнесе. Методологические и практические основы построения контроллинга в организациях. 2-е изд. Москва : «Фнансы и статистика», 2002. 256 c.

9. Карпова Н. В. Политико-культурные основы управления в политическом менеджменте : XXI Международная конференция памяти профессора Л. Н. Когана «Культура, личность, общество в современном мире: методология, опыт эмпирического исследования» (г. Екатеринбург, 22-23 марта 2018 г.). Екатеринбург : Урфу, 2018. С. 2079-2090. URL: http://elar.urfu.ru/bitstream/10995/59071/1/978-5-91256-403-1_2018_221.pdf (дата звернення: 24.09.2021).

10. Кіпа Д. В. Визначення впливу зовнішнього середовища на фрормування конкурентної стратегії підприємства. Бізнес Інфрорм. 2014. № 9. С. 322-329.

11. Лапыгин Ю. Н. Теория организаций : учеб. пособие для вузов. Москва : ИНФРА-М, 2007. 310 с.

12.Лопатников Л. И. Общеэкономический и экономико-математический объяснительный словарь. URL: http://lopatnikov.pro/slovar/s/sreda-vneshnyaya-sreda/

13. Мескон М. Х., Альберт М., Хедоури Ф. Основы менеджмента / пер. с англ. Москва : Дело, 1998.704 с.

14. Натрошвілі С. Г. Стратегічне управління вищим навчальним закладом: теорія, методологія, практика : монографрія. Київ : КНУТД, 2015. 320 с.

15. Нестеров А. К. Внешняя среда организации. Энциклопедия Нестеровых. 2019. URL: http://odiplom.ru/ lab/vneshnyaya-sreda-organizacii.html

16. Орлова К. Є. Оцінка нестабільності зовнішнього середовища підприємств добувної промисловості Житомирської області. Zprávy vědeckéideje - 2012 : materiály VIII vědecko-praktická konference. Díl. 5. Ekonomické vědy, Praha : Publishing House «Education and Science» S.r.o., 2012. S. 79-82.

17. Петков О. І. Методичні підходи до оцінювання економічної ефективності підприємств харчової галузі України. Причорноморські економічні студії. 2019. Вип. 42. С. 35-39. 
18. Петренко Н. І., Бутинець Т. А. Середовище контролю: поняття, природа, соціальна цінність. Проблеми теорії та методології бухгалтерського обліку, контролю і аналізу. 2011. № 2(20). С. 371-384.

19. Полутова М. А. Теоретико-методологические подходы к организации как открытой системе: внутренняя и внешняя среда организации. Вестник Забайкальского государственного университета. 2014. № 3(106). С. 75-87.

20. Примак Т. О. Маркетинг : навч. посіб. Київ : МАУП, 2004. 228 с.

21. Репина Е. А., Анопченко Т. Ю., Володин Р. С. Менеджмент : учебное пособие. Ростов н/Дону : Изд-во АкадемЛит, 2015, 316 с.

22. Савіна Г. Г., Скібіна Т. І. Фактори зовнішнього та внутрішнього впливу на есрективність управління підприємством комплексу комунальних послуг. Ефеективна економіка. 2016. № 12. URL: http://www.economy.nayka.com.ua

23. Чернышов В. Н., Чернышов А. В. Теория систем и системный анализ : учеб. пособие. Тамбов : Изд-во Тамб. гос. техн. ун-та, 2008. 96 с.

24. Шершньова 3. Є. Стратегічне управління : підручник. 2-ге вид., перероб. і доп. Київ : КНЕУ, 2004. 699 с.

25. Шморгун Л. Г. Менеджмент організацій : навчальний посібник. Київ : Знання, 2010. 452 с. URL: https://pidru4niki.com/10561127/menedzhment/zovnishnye_seredovische_organizatsiyi_derzhavne_regulyuvannya_ chinnik_vplivu (дата звернення: 16.10.2021).

26. Щебликіна І. О., Грибова Д. В. Основи менеджменту : навчальний посібник. Мелітополь : ВБ «ММД», 2015. 479 c. URL: https://pidru4niki.com/75122/menedzhment/zovnishnye_seredovische_organizatsiyi\#195

\section{REFERENCES:}

1. Boljshoj ekonomycheskyj slovarj [Big Dictionary of Economics] / pod red. A. N. Azrylyjana (1999). Moskow: Institut novoy ekonomiki. (in Russian)

2. Vasylenko V. A., Tkachenko T. I. (2003) Strateghichne upravlinnja: navch. posib [Strategic management: textbook]. Kyjiv: CUL. (in Ukrainian)

3. Ghorjelov D. O. (2010) Strateghija pidpryjemstva: navch.-metod. posib [Enterprise strategy: a textbook]. Kharkiv: KhNADU. (in Ukrainian)

4. Ghutorova O. O. (2009) Osnovy menedzhmentu: navchaljnyj posibnyk [Fundamentals of management: a textbook]. Kharkiv: KhNAU. (in Ukrainian)

5. Degtyareva Yu. V. (2016) Komponenty vneshnego i vnutrennego okruzheniya investitsionnogo proekta [Components of the external and internal environment of the investment project]. Naukoviy visnik Uzhgorods'kogo natsional'nogo universitetu. Seriya: Mizhnarodni ekonomichni vidnosini ta svitove gospodarstvo, vol. 7, 1, 114-117. (in Ukrainian)

6. Dzjuba S. Gh., Ghajdaj I. Ju. (2012) Zaghaljna kharakterystyka zovnishnjogho seredovyshha funkcionuvannja pidpryjemstv [General characteristics of the external environment of enterprises]. Aktualjni problemy ekonomiky, 1 , 144-156. (in Ukrainian)

7. Kaplina O. V., Zaychenko D. A. (2005) Otsenka konkurentosposobnosti predpriyatiya na osnove protsessnogo pokhoda [Assessment of the competitiveness of the enterprise on the basis of a process campaign]. Marketing, no. 4, pp. 24-38. (in Russian)

8. Karminskiy A. M., Olenev N. I., Primak A. G., Fal'ko S. G. (2002) Kontrolling v biznese. Metodologicheskie i prakticheskie osnovy postroeniya kontrollinga $v$ organizatsiyakh [Controlling in business. Methodological and practical bases of construction of controlling in the organizations]. Moskow: Finance and statistics. (in Russian)

9. Karpova N. V. (2018) Politiko-kul'turnye osnovy upravleniya v politicheskom menedzhmente [Political and cultural foundations of management in political management]: XXI Mezhdunarodnaya konferentsiya pamyati professora L. N. Kogana «Kul'tura, lichnost', obshchestvo v sovremennom mire: metodologiya, opyt empiricheskogo issledovaniya» (g. Ekaterinburg, 22-23 marta 2018 g.). Ekaterinburg. Retrieved from: http://elar.urfu.ru/bitstr eam/10995/59071/1/978-5-91256-403-1_2018_221.pdf (accessed 24 September 2021).

10. Kipa D. V. (2014) Vyznachennja vplyvu zovnishnjogho seredovyshha na formuvannja konkurentnoji strateghiji pidpryjemstva [Determining the impact of the external environment on the formation of competitive strategy of the enterprise]. Biznes Inform, no. 9, pp. 322-329.

11.Lapighyn Ju. N. (2007) Teoryja orghanyzacy]: ucheb. posobye dlja vuzov [Theory of organizations: textbook. manual for universities]. Moskow: Delo. (in Russian)

12. Lopatnykov L. Y. (2012) Obshheekonomycheskyj y ekonomyko-matematycheskyj obj'asnyteljnij slovarj [General economic and economic-mathematical explanatory dictionary]. Retrieved from: http://lopatnikov.pro/slovar/s/ sreda-vneshnyaya-sreda/ 
13. Meskon M.Kh., Aljbert M., Khedoury F. (1998) Osnovi menedzhmenta [Fundamentals of management] / per. s anghl. Moskow: Delo. (in Russian)

14. Natroshvili S. Gh. (2015) Strateghichne upravlinnja vyshhym navchaljnym zakladom: teorija, metodologhija, praktyka: monoghrafija [Strategic management of higher education: theory, methodology, practice: monograph]. Kyiv: KNUTD. (in Ukrainian)

15. Nesterov A. K. (2019) Vneshnjaja sreda orghanyzacyy [The external environment of the organization. Encyclopedia of the Nesterovs]. Encyklopedyja Nesterovikh. Retrieved from: http://odiplom.ru/lab/vneshnyaya-sreda-organizacii.html

16. Orlova K. Je. (2012) Ocinka nestabiljnosti zovnishnjogho seredovyshha pidpryjemstv dobuvnoji promyslovosti Zhytomyrsjkoji oblasti [Assessment of the instability of the external environment of the extractive industries of Zhytomyr region]. Zprávy vědeckéideje. Materiály VIII vědecko-praktická konference. Díl. 5. Ekonomické vědy, Praha: Publishing House «Education and Science» s.r.o. pp. 79-82. (in Ukrainian)

17. Petkov O. I. (2019) Metodychni pidkhody do ocinjuvannja ekonomichnoji efektyvnosti pidpryjemstv kharchovoji ghaluzi Ukrajiny [Methodical approaches to assessing the economic efficiency of food industry enterprises in Ukraine]. Prychornomorsjki ekonomichni studiji, no. 42, pp. 35-39. (in Ukrainian)

18. Petrenko N. I., Butynecj T. A. (2011) Seredovyshhe kontrolju: ponjattja, pryroda, socialjna cinnistj. Problemy teoriji ta metodologhiji bukhghaltersjkogho obliku, kontrolju i analizu [Control environment: concept, nature, social value], no. 2(20), pp. 371-384. (in Ukrainian)

19. Polutova M. A. (2014)Teoretyko-metodologhycheskye podkhodb k orghanyzacyy kak otkritoj systeme: vnutrennjaja y vneshnjaja sreda orghanyzacyy. Vestnyk Zabajkaljskogho ghosudarstvennogho unyversyteta, no. 3(106), pp. 75-87. (in Ukrainian)

20. Prymak T. O. (2004) Marketyngh: navch. posib. [Marketing: textbook. way]. Kyiv: MAUP, 228 p. (in Ukrainian)

21. Repyna E. A., Anopchenko T. Ju., Volodyn R. S. (2015) Menedzhment: uchebnoe posobye [Management: a textbook]. Rostov n/Donu: Yzd-vo AkademLyt. (in Russian)

22. Savina Gh. Gh., Skibina T. I. (2016) Faktory zovnishnjogho ta vnutrishnjogho vplyvu na efektyvnistj upravlinnja pidpryjemstvom kompleksu komunaljnykh poslugh [Factors of external and internal influence on the efficiency of enterprise management of the utility complex]. Efektyvna ekonomika, no. 12. Retrieved from: http://www.economy.nayka.com.ua

23. Chernishov V. N., Chernishov A. V. (2008) Teoryja system y systemnij analyz: ucheb. posobye [Systems theory and systems analysis: textbook. allowance]. Tambov: Yzd-vo Tamb. ghos. tekhn. un-ta. (in Russian)

24. Shershnjova Z. Je. (2004) Strateghichne upravlinnja: pidruchnyk. 2-ghe vyd., pererob. i dop [Strategic management: a textbook. 2nd ed., Revised. and ext]. Kyiv: KNEU. (in Ukrainian)

25. Shmorghun L. Gh. (2010) Menedzhment orghanizacij: navchaljnyj posibnyk [Management of organizations: a textbook]. Kyiv: Znannja. Retrieved from: https://pidru4niki.com/10561127/menedzhment/zovnishnye_seredovische_organizatsiyi_derzhavne_regulyuvannya_chinnik_vplivu

26. Shheblykina I. O., Ghrybova D. V. (2015) Osnovy menedzhmentu: navchaljnyj posibnyk [Fundamentals of management: a textbook]. Melitopolj: «MMD». Retrieved from: https://pidru4niki.com/75122/menedzhment/zovnishnye_seredovische_organizatsiyi\#195/ 